\title{
THE ASSOCIATION BETWEEN FREQUENCY OF ANTENATAL CARE VISIT AND ANEMIA IN PREGNANT WOMEN IN PEGADUNGAN IV COMMUNITY HEALTH CENTER, WEST JAKARTA
}

\author{
Izza Suraya, Siti Fariha, Nanny Harmani \\ Study Program of Public Health, Universitas Muhammadiyah \\ Prof Dr. HAMKA, Jakarta
}

\begin{abstract}
Background: According to the Ministry of Family Health, as many as $40 \%$ of maternal deaths are caused by bleeding. The risk of bleeding will be greater if pregnant women experience anemia. Basic Health Research in 2013 showed that the prevalence of anemia in pregnant women was $37.1 \%$. The number of pregnant women with anemia at Pegadungan IV community health center, Kalideres, West Jakarta in 2016 was 57.3\%.The magnitude of this number may influence by maternal Antenatal Care (ANC) visit during pregnancy. This study aimed to determine the relationship between the frequency of ANC visits and anemia in pregnant women.

Subjects and Method: This was a cross-sectional study. The study was conducted at Pegadungan community health center, West Jakarta. A sample of 90 pregnant women in third semester was selected for this study. The dependent was anemia. The independent variables were antenatal care visit. The confounding factor included age, parity, education, employment status, and family income. The data were collected by questionnaire and maternal and child book monitor. The data were analyzed by a logistic regression.

Results: After controlling for the confounding factors, the risk of anemia in pregnant women increased with $\mathrm{ANC}$ visit $<4$ times $(\mathrm{OR}=1.97 ; 95 \% \mathrm{CI}=1.34$ to 2.89; $\mathrm{p}=0.001$ ).

Conclusion: After controlling for the confounding factors, the risk of anemia in pregnant women increases with ANC visit < 4 times.
\end{abstract}

Keywords: anemia, antenatal care visit, pregnant women

\section{Correspondence:}

Izza Suraya. Study Program of Public Health, Universitas Muhammadiyah Prof Dr. Hamka, Jakarta. Email: izza_suraya@uhamka.ac.id.

Mobile: +6281311241628.

Mid-International Conference in Public Health, Best Western Premiere Hotel, Solo, Indonesia, 18-19 April 2018 | 184 https://doi.org/10.26911/mid.icph.2018.03.20 